\title{
Positing Alterity, Positing Metaphysics: A short note on Alistair Miller on Levinas
}

\section{Paul Standish (UCL Institute of Education)}

'My attitude towards him is an attitude towards a soul. I am not of the opinion that he has a soul.' - Wittgenstein, 1953, p. 178

In 'Levinas: Ethics of Mystification?', Alistair Miller presents a searing indictment of the philosophy of Emmanuel Levinas and a dismissal of claims for its importance for education (Miller, 2017). In doing so, he attempts to provide an exegesis of salient aspects of Levinas's philosophy, and he is attentive to, quotes extensively, and in some respects emulates some of the phrasing that recurs both in Levinas's major texts and in wider readings of his work. He also refers to the writings of some of those who have taken up and interpreted Levinas's philosophy in relation to education, though he does not follow through in any detail on this work. Indeed, a single paragraph (on p. 525) almost wraps up his treatment of four readings of Levinas in relation to education (by Christine Winter, Anna Strhan, Sharon Todd, and myself), albeit that there are further equally brief references to some of these authors later in his discussion. Denise Egéa-Kuehne receives similarly brief treatment in a subsequent paragraph. Inevitably, this means that the quotations he extracts are presented without contextualisation, and the lines of connection drawn are attenuated. Miller is right that Levinas's most familiar ideas are vulnerable to a sentimental distortion, and there is every reason to resist this. His later remarks seem to relate this to a consoling utopian vision (p. 526) and an ideology of social justice (p. 536). It would have been good to have had this better illustrated. Such a sentimentalised reading would indeed amount to a disservice to Levinas himself.

Yet the objection, it turns out, is not just to sentimentalised interpretations of Levinas: Miller's account does little to save Levinas himself from this charge. If Miller were right in this characterisation, there would, once again, be every reason to support him. But, in fact, he is profoundly wrong, and the edifice of argument that he builds is shaky from the ground up.

I shall not try to show this through a thorough-going examination of the account that Miller develops. Miller has done some homework and not everything he says is wide of the mark; but the errors in what he has to say are pervasive, and it is difficult to know where to begin. How in a succinct way can one address the more fundamental presuppositions Miller makes, which stand in the way of his understanding of Levinas? Fortunately, a substantial critique of his paper has been provided by Soyoung Lee, and this goes some considerable distance towards demonstrating the nature of the problems (Lee, 2018). What I propose to do, by contrast, is to track one telltale aspect of his phrasing and to show how a careful unpacking of its implications can indicate how and why things go wrong. 
Before doing this, I shall make some brief related remarks about the terms within which Miller sets up his discussion, which are important, I think, for setting the context. In the abstract to the paper, Miller writes:

[T] he notion that the subject can be detached from its worldly beingthat one can posit a primordial metaphysical pre-conscious prephenomenal self which stands in ethical relation to a primordial metaphysical pre-conscious pre-phenomenal Other-is highly questionable (p. 524).

The term 'metaphysical' and its cognates occurs five times in the abstract and twenty-six times in the main text. The paper is not necessarily any the worse for that, but the recurrent usage repays some attention. The fate of metaphysics in philosophy is a curious one. In much philosophy over the last century or so, the term has acquired a negative force, referring in particular to the tendency to stand outside the world in order to try to describe it. An example of this criticism is to be found, for example, in Wittgenstein's disparagement of philosophical thought that becomes disconnected from the 'rough ground' of everyday experience and where, say, the machinery of a philosophical system turns smoothly precisely because it is spinning in mid-air, without the friction that would give it purchase (Wittgenstein, 1953, \#107).

There is good reason to be suspicious of forms of speculation and theorising that lose touch with reality in this way. But, in another sense, metaphysics is not to be dispensed with so easily. Notions of time, thing, change, cause, intention, substance, and indeed soul are built into our ways of thinking and being, realised in different cultural and historical circumstances as they clearly are. ${ }^{i}$ In a sense, such notions are unavoidable for human beings. The appealing ironic understatement of Gilbert Ryle's description of philosophy as being about 'chaps and things' (ref.), and of Wilfred Sellars's remark, in more American idiom, that the aim of philosophy is 'to understand how things in the broadest possible sense of the term hang together in the broadest possible sense of the term' (Sellars, 1960, p. 1), is a quiet testimony to this unavoidability of metaphysics. Insistently negative use of the term, by contrast, can become a sledgehammer that obliterates thought there where most it is needed; and it can lead to caricature. Thus, when Miller remarks, of Levinas's work, that 'the exercise appears to be little more than an attempt to vivify a metaphysical relation between metaphysical entities devoid of human phenomenal attributes, and to imbue these entities with an aura of meaning and significance' (p. 530), one must wonder in whose mind this metaphysical relation exists. The overused but not inappropriate slogan that is associated with Levinas (and which indeed Miller quotes) - ethics before ontology - clearly implies that whatever ethics is, it is not a matter of entities! So the two realms that Miller identifies - as when, for example, he refers to 'a one-to-one correspondence between the phenomenal and preontological realms' (p. 531) - do not exist other than in a fantasised reconstruction. Moreover, the emphasis on ethical priority in Levinas seems to have been taken by Miller to imply chronological priority, when in fact Levinas's concerns are more to do with the presuppositions or 
preconditions of aspects of our world (in a way that is closer, for example, to notions of logical, not temporal priority). Furthermore, the force of alterity figured in what Levinas calls the 'concrete abstraction' of the Face is weakened and radically distorted where this is taken to be a 'face-to-face' relation. The latter expression implies a reciprocity that Levinas is at pains to resist: it is crucial to his account that this singularising asymmetry in relation to the other is felt in the weight of the first-person perspective. No wonder this is such a tangle! How, in the light of this, can Levinas's philosophy come into view?

As indicated above, however, my purpose here is not to answer this question in the round ${ }^{\mathrm{ii}}$ but to focus on one detail, a detail of expression that I take to be a give-away of the extent of the misunderstanding. This is the notion of positing, which runs through Miller's discussion. When he questions the notion that 'one can posit a primordial metaphysical preconscious pre-phenomenal self' standing in ethical relation to 'a primordial metaphysical pre-conscious pre-phenomenal Other' (p. 524), this is clearly intended as an accurate description of Levinas's views. Similarly, he later claims that it is by "positing the stranger, neighbour or "Other" as transcendent in their "alterity" that Levinas is able to "establish that ethics (or metaphysics qua ethics) "precedes ontology" (p. 525). The distinction Levinas draws between existence and existents is then hidden and confused by the assertion that

once existence is posited as something independent of the existent or subject, and prior to consciousness (and hence to the 'outer' world and relations with others), the way is opened to positing the other person as possessed of 'exteriority' and 'alterity', as the 'absolutely other' with whom a primordial relationship (or relation) is possible in the metaphysical form of a 'face to face' encounter (pp. 527-528).

Yes, this certainly sounds confused, and the confusion is compounded by Miller's phrasing of his puzzlement over how 'existence [could] be posited independently of existents, and prior to consciousness, as a "metaphysical" fact or truth' (p. 528). Moreover, he chastises Levinas for negligence in his thinking:

to posit 'solitude' (p. 43), 'vulnerability' (Levinas, 1998, pp. 48, 54), gentleness (Levinas, 1969, p. 150), 'destitution' (p. 200), and so forth, as metaphysical pre-ontological qualities (see pp. 54-58) is to neglect that the concepts and experiences these terms have come to designate as part of common linguistic usage are only meaningful in relation to other concepts and experiences: for example, in the case of 'solitude', those designated by the terms 'relationship', 'coexistence', 'companionship', 'community', 'love' and 'friendship' (Miller, 2017, p. 528).

Against what he takes to be Levinas's view that a humane ethics simply cannot be grounded empirically, Miller draws attention to the importance of the evidence of history. One 'only has to consider the Holocaust' to realise 
that "neither sympathetic personal relations nor "totalising" belief systems, including conventional religious systems that posit a deity or another world, are adequate to the task' (p. 532). So it seems that for conventional religious believers also, the reality of the god they live by concerns the existence of a deity or another world as posited. Apparently, Kant's moral law and (the surely very different case of Rawls's original position are also similarly posited (p. 534). But can it be right to say that the religious believer posits the existence of a deity? Is 'I posit that there is one god' to translate Credo in unum deum?

The emphasis on positing in Miller's account points, in my view, to a systematic misunderstanding in his reading of Levinas. One characteristic of this is the presumption that those pre-ontological aspects of human being and world that Levinas draws attention to must be entities - that is, beings, existents - when in fact they are more like conditions or necessary aspects of experience and, hence, dimensions of the world. That Levinas is not talking about entities in these contexts is something I have made clear above. To be or not to be is not the question. A second characteristic can be seen if we think of the way that positing is something that one might choose to do - along the lines, for example, of a speculation. It would be a paltry and, in so many ways, mistaken conception of religious and ethical belief to suppose that we choose to believe. We choose cars and we choose t-shirts, but it would be odd to say that we choose to believe that 'Jesus is my saviour' or that apartheid is wrong. To think otherwise would be fundamentally to misconceive the kind of phenomenologically attuned description that Levinas is trying to provide. The two-worlds fantasy - and the idea, in any case, that these two worlds are posited - is a distortion of this description, and it colludes with the twin-strategy Miller adopts of empirical and transcendental readings of the work. Together these block the way to making sense of the expressions from Levinas that Miller recites.

Miller's usage of the term 'positing' is, as far as I can see, the everyday one, ${ }^{\text {iii }}$ which typically has the sense of putting something forward, positioning it, or placing it, perhaps as a possible source of explanation. Certainly there are occasions when we posit things, in order perhaps to try to make sense of the world. Within the terms of a particular kind of enquiry - and now surely not a very fruitful one - it would make sense to speak of, say, positing the existence of god as a way of addressing the problem of origins and first causes. Intellectually this would appear to make some sense (that is, it is a coherent sense of positing), notwithstanding the fact that it is difficult now to believe that this takes us very far in understanding the nature of religion or of the world or of anything else. This is very far from what Levinas is doing in his philosophy.

It is, as I have tried to show, the idea that Levinas is positing alterity that provides the basis for the barriers to understanding that Miller goes on to build. In concluding, let me criticise just three mainstays of this misconception. First, it is a mistake to think that Levinas 'posits' a 'primordial metaphysical pre-conscious pre-phenomenal self (italics added), whatever kind of spook this might be; Levinas nowhere conceives the self in these terms. Second, if we concede for a moment Miller's phrasing that 'our experience of the world and of ourselves can only be conceived in social, 
cultural and linguistic terms', then it is precisely these terms, these aspects of our experience, that Levinas's philosophy seeks to illuminate. In fact, he is asking what society, culture, and language are, and this is anything but other-worldly. Third, Levinas is not in the business of constructing metaphysical abstractions or indulging in an esoteric discourse. His words drawing on such powerful flesh-and-blood figures as the widow, the orphan, and the stranger, and with the visceral imperative of giving the other the bread from one's mouth, with evocations of the pain of labour, of woundedness, of sickening and ageing - are far from being a self-referential lexicon but chosen in order to break through those accustomed, abstracted, third-person theorisations that mark so much of professionalised moral philosophy. It is not unreasonable to hope that language of this kind might also break through those sometimes anaesthetising, familiar debates between moral cognitivism, character education, and virtue ethics - the standard territory of theorisations of moral education.

At several points in the text, Miller has recourse to a conception of language that, he seems to believe, can dispel mystification and restore good sense. He appeals to 'accepted criteria for evaluating prose (i.e. by reference to the rules of grammar, syntax and logic)' (p. 529) and to a notion of the ordinary ('correspondence to ordinary linguistic usage', ibid.; 'in the sense we ordinarily understand the term', p. 531; 'the capacity of ordinary people', p. 535). Such appeals are welcome, but too great a confidence in 'plain prose' can also become complacent, and there is reason, as Wittgenstein saw, to seek a conception of the grammar of an expression that relies less on rules of correctness (e.g. according to 'standard English usage', ensuring number agreement, correct verb form, and so on) and more on its coherence in a particular context and practice - in short, within the particular language game. When he writes 'My attitude towards him is an attitude towards a soul. I am not of the opinion that he has a soul', his purpose is a grammatical one in that he is trying to illustrate something of the place of the idea of the soul in ordinary ways of thinking. 'Poor old soul!' as it is sometimes said. This is different from debating whether someone has a soul or what the soul is, exercises that Wittgenstein might instance as examples of language and thought spinning in mid-air. My attitude to him is an attitude to a soul. I do not posit that he has a soul.

But let me approach this from another angle also. As I remarked above, Miller's usage of 'positing' is the everyday one, and there is no suggestion that he is alluding to the complex notions of (self-)positing that emerge so powerfully in Fichte and Hegel. Certainly, one can feel the appeal of the ordinary against such technical abstractions. And yet Fichte and Hegel were addressing the reality of what the human subject is and its relation to experience and to anything we could call the world. Their speculations have a bearing on what the ordinary can be. Conversely, it is the case that too quick an appeal to such ordinary but elusive notions as society, culture, and language can be a way of avoiding the question of just what these amount to. In a very different vein, Levinas also has developed a philosophy that examines searchingly and describes with great subtlety and accuracy the place of such institutions in our everyday lives, not to mention in our professional lives in education. While Miller's paper suffers from a 
degree of complacency in its blocking these kinds of enquiry and insight, it also teeters on the brink of condescension in its final sorry assessment of Levinas:

When considered as a work of poetic or prophetic incantation, as myth, Levinas's work is endlessly fascinating. But as philosophy, as ethics, even as a creed, it has, I have argued in this article, little to offer. When the mystical trappings of the ethics of the Other are stripped away, what remains, I fear, is more akin to a totalising system of the kind Levinas detests (p. 535).

If Levinas's philosophy is so woefully inadequate, it is hard to see where the fascination can lie! Is Miller really so fascinated by 'poetic' writing or mythmaking that has no bearing on reality? What would be its value? In fact, the distinction between poetry and prose is another that Miller has relied on, yet the coherence and consequences of the distinction, contentious and unsteady as it is, and the fault-line between philosophy and literature that has run through philosophy since ancient times, is never directly addressed.iv Does Miller's indictment of consoling utopian visions and of the ideology of social justice extend to Levinas himself? It is not clear where Miller stands on this, but his dismissal of the philosophical value of Levinas's thought itself makes the question less significant.

I have found there to be something severe, demanding, and far from consoling in Levinas's philosophy. I have found that what I have called the 'visceral' quality of some of his writing speaks to the difficulty of reality and the singularising force of the ethical - that is, the weight of responsibility. The visceral is there also in what one might think of as his allegorical invocation of the orphan and the stranger: but perhaps this is less allegory than metonymy, given the countless dispossessed, displaced, hungry strangers who in fact walk the earth. The visceral is there in his writings about politics and about war. And it is there too in the image he draws from Vasily Grossman of the nape of the neck - the neck of the person standing in front, in the queue for food in the camp, at Treblinka or Maidanek. These are anything but metaphysical abstractions.

There is also, I think, something obsessive about his philosophy, as if a singular thought reverberated through the whole. Is there reason to be troubled by this? To the extent that there is, it must also be recognised that this is a weakness of a kind quite other than anything Miller describes. To explore this is beyond the scope of the present discussion. Let me conclude instead with a brief comment on the approach I have adopted in the above critique.

\section{An analytical critique, a continental project?}

I am prompted to make this comment by the suggestion of an anonymous reviewer, who claims that Miller's misguided commentary on Levinas' work is caused by his use of an analytical philosophical framework and the application of its assumptions to a continental philosophical project. The same reviewer wonders also whether, even though I may be attracted to 
insights provided by continental philosophy, I am so deeply embedded in the analytical tradition that I am unable to go further in identifying the problem in Miller's stance and exposing its deep paradoxes. I have, it seems, failed to see the fundamental problem of Miller's mistaking Levinas's work for a metaphysical project: in Miller's claims that Levinas's work is 'little more than an attempt to vivify a metaphysical relation between metaphysical entities devoid of human phenomenal attributes,' and that for Levinas, 'the subject can be detached from its worldly being-that one can posit a primordial metaphysical pre-conscious pre-phenomenal self,' he seems, according to the reviewer, to be as far as can be from understanding Levinas's project. My mistake is that, aside from some incidental criticisms, the main charge I muster against Miller is, evidently, that he has failed to give sufficient context to the brief remarks from philosophers of education interpreting Levinas.

I find it surprising that I am understood in this way. My observation regarding Miller's somewhat casual treatment of the philosophers of education in question is a preamble to my main purpose in this discussion. In broaching the latter, I state that 'the edifice of argument that he [Miller] builds is shaky from the ground up'; and, further, that 'the errors in what he has to say are pervasive', with the consequence that 'it is difficult to know where to begin'. To refine the problem, I have elected to concentrate on one significant, recurrent feature of Miller's expression, which I take to be a telltale sign of his mistaking Levinas's descriptive phenomenological commitments for a metaphysical project: metaphysical, that is, in the bad sense - stepping outside the world and positing the existing of things. The emphasis on positing, as I claim early on in my discussion, points to a systematic misunderstanding in Miller's reading of Levinas. The quotations (in the above paragraph) that the reviewer uses to make the point that I supposedly miss are precisely those around which my own discussion has revolved.

I wanted to write a short response in order to appeal to the sceptical reader. Closer attention to Levinas's texts and careful exegesis of the several decades of scholarship and criticism that his writings have stimulated ${ }^{v}$ would hardly have been likely to cut much ice with those impressed by Miller's line of argument. Indeed, such literature would equally fall foul of the misreading that his text exemplifies. In any case, a more rounded account, more explanatory of Levinas but again with the sceptical reader in mind, is already available in Lee's fine critical response to Miller, which was mentioned at the start: its three-part structure provides an attack on the suggestion that Levinas's ethics is a 'system', clear explanation of Levinas's idea of the face, and elaboration of the importance of ethics without return (Lee, 2018). vi If the philosophers to whom I do make passing reference are more familiar or more acceptable to readers such as Miller, then this seems desirable - even desirable pedagogically, one might say - as a means of advancing understanding. vii

On the whole, in philosophy, it is easy to go wrong if one takes up an idea without some awareness of its discursive context: that is, of the background texts, the connotations of central expressions, and the lineage of arguments. Think of reading A.J. Ayer without some sense of the 
background in Russell's philosophy and logical positivism, of coming across the idea of 'second nature' in a contemporary text without awareness of John McDowell's work and its Aristotelian inheritance, of trying to understand recent discussions of knowing-how and knowing-that without knowing of the work of Gilbert Ryle. The point here is not to reprimand the reader who has not done all this but to encourage the replacement of headstrong assumptions regarding a text with something closer to intellectual humility. Traditions of philosophical enquiry may sometimes seem alien and hard to penetrate, and sometimes they may become ideological and moribund, but it is unlikely that those who have developed them are simply fools - or just myth-makers or mystics or ideologues or 'poets'.

Finally, it is a failure of philosophy if we are to acquiesce in the diagnosis that the cause of the problem here is that an analytical philosophical framework has been applied to a continental philosophical project. Setting aside for the moment the cumbersome and obstructive nature of the analytical/continental distinction, such a diagnosis invites an unhealthy relativism, where each approach is equally 'valid' but where they cannot engage with one another. I do not see Miller as welcoming such a verdict. In fact, to think that way is a threat to philosophy and to reason itself: it is a failure to follow the argument where it leads. And following the argument, in the sense that is most important for philosophy, is not to be reduced to the application of the skills of critical thinking or to the vaunting of over-hasty or simplistic notions of clarity. It involves patience and humility in the face of what one does not at first understand, and a readiness to learn more. ${ }^{\text {viii }}$

\section{References}

Egéa-Kuehne, D. (ed.)(2008) Levinas and Education: At the Intersection of Faith and Reason (London, Routledge).

Lee, S. (2018) 'Ethics is an optics': ethical practicality and the exposure of teaching, to be confirmed.

Miller, A. (2017) Levinas: Ethics or Mystification?, Journal of Philosophy of Education, 51.2, pp. 524-537.

Putnam, H. (2008) Jewish Philosophy as a Guide to Life: Rosenzweig, Buber, Levinas, Wittgenstein (Bloomington, IN, Indiana University Press).

Sellars, W. (1960) Philosophy and the Scientific Image of Man, Two lectures given at the University of Pittsburgh in December 1960.

Standish, P. (2018) 'Nothing but Sounds, Ink-Marks'-Is Nothing Hidden? Must Everything Be Transparent?, Danish Yearbook of Philosophy, 51.1, pp. 71-9.

Standish, P. (2009) Levinas and the Language of the Curriculum, in: D. EgeaKuehne, Levinas and Education: at the intersection of faith and reason (London and New York, Taylor and Francis).

Standish, P. (2008) Education for Grownups, A Religion for Adults: scepticism and alterity in Cavell and Levinas, Ethics and Education, pp. 73-91. 
Standish, P. (2005) Towards an Economy of Higher Education, Critical Quarterly, 47.1-2, 53-71.

Standish, P. (2002) Humanism, Antihumanism, the Inhuman, in: W. van Haaften, A. Musschenga, M. Slors, and B. Spiecker (eds) Personal and Moral Identity, Dordrecht: Kluwer.

Standish, P. (2001a) Ethics Before Equality: Moral Education After Lévinas, Journal of Moral Education, 30:4, 339-348.

Standish, P. (2001b) Data Return: the sense of the given in educational research, Journal of Philosophy of Education, 35:3, 497-518.

Strhan, A. (2012) Levinas, Subjectivity, Education: Towards an Ethics of Radical Responsibility (Oxford, Wiley-Blackwell).

Todd, S. (2003) Learning from the Other: Levinas, Psychoanalysis, and Ethical Possibilities in Education (Suny Series, Second Thoughts) (New York, SUNY).

Williams, E., and Standish, P. (2014) Sound not Light: Levinas and the Elements of Thought, in: Guoping Zhao (ed.) Levinas and the Philosophy of Education, special issue of Educational Philosophy and Theory.

Wittgenstein, L. (1953) Philosophical Investigations, trans. G.E.M. Anscombe (Oxford, Basil Blackwell).

Zhao, G. (ed.)(2018) Levinas and the Philosophy of Education (London, Taylor \& Francis)

\footnotetext{
i For some readers, 'soul' may sit awkwardly in the list. If its substitution by 'mind' or 'spirit' or 'psyche' were to make it more acceptable, this would also underline the ways in which these metaphysical assumptions are differently realised.

ii It does seem strange that Miller embarks on a project of this kind without reference to prominent monographs on Levinas and education. Sharon Todd's Learning from the Other (2003) has rightly been influential, while Anna Strhan's Levinas, Subjectivity, Education: Towards an Ethics of Radical Responsibility (2012) is outstanding for its range and depth. By the same token, a recent collection edited by Guoping Zhao, Levinas and the Philosophy of Education (2018) would have been worthy of attention, as would Denise Egéa-Kuehne's edited volume, Levinas and Education: At the Intersection of Faith and Reason (2008), which was a significant development in the field.

iii He is not appealing to the complex notion of (self-)positing as it emerges in Fichte and Hegel. Nor to any more specialised sense.

iv The 2018 special issue of the Journal of Philosophy of Education, edited by Liam Gearon and Emma Williams, in part addresses this.

$\checkmark$ Reviewers also recommended this.

vi Elaboration of my own views regarding Levinas and education can be found in, for example, Standish, 2001a, 2001b, 2005, and 2009, and Williams and Standish, 2014.

vii But I say if more familiar, if more acceptable. It is to be lamented that Wittgenstein is not generally in favour in Anglophone philosophy departments at present, though this is certainly not because anyone regards him as a 'continental' philosopher. But it is ironic that the reviewer I am
} 
responding to here takes Wittgenstein to epitomise the analytical tradition. The reviewer cites the phrase 'nothing is hidden', in the Philosophical Investigations (Wittgenstein, 1953, \#435), as evidence of the extreme contrast between Wittgenstein's and Levinas's views: Levinas's work is all about the hidden! This seems to me itself to involve a lack of attention to the context of Wittgenstein's words and his style of expression, as well as to wider aspects of his work (see Standish, 2018). The hidden that Wittgenstein is denying is the hidden of 'mental operations' - the idea that to understand the mind we must look beyond our ordinary forms of expression and seek to uncover the brain processes that are its real location. This is not a denial of the hidden in the ordinary sense (for example, that an expression can be sincere or calculated to deceive), any more than Levinas's concern with the hidden is a preoccupation with the workings of brains. Anyone who sees such a stark opposition between these two philosophers would do well to read Bob Plant's Wittgenstein and Levinas: Ethical and religious belief (Plant, 2005). Plant's book falls outside the mainstream of Levinas scholarship in that he comes to this from a predominantly analytical background. Also of note in this respect is Michael Morgan's Discovering Levinas (Morgan, 2007). As Morgan explains in the Preface to the book, 'Reading Levinas, I brought with me the tradition of Anglo-American philosophy, as well as my own understanding of the history of Western philosophy. Thinking about Levinas, I also thought about Wittgenstein and readers of him, especially Stanley Cavell, and other philosophers as well: Hilary Putnam, Alasdair MacIntyre, Charles Taylor, and John McDowell' (pp. xii-xiii; regarding connections with Cavell, see also Standish, 2008). A page later, the list is extended to include Donald Davidson, Onora O'Neill, and Christine Korsgaard, albeit that these receive rather less attention. And the ensuing conversation is one that talks with these philosophers, as well as with Heidegger and Derrida, and with Franz Rosenzweig and Walter Benjamin the whole text circling around the central philosophical questions: how do I understand the human condition, and how do I live? (Morgan, 2007, p. xii). In a different vein, Hilary Putnam's Jewish Philosophy as a Guide to Life: Rosenzweig, Buber, Levinas, Wittgenstein (2008) also works across accustomed philosophical boundaries.

viii I would like to thank Nigel Tubbs for valuable discussions in relation to aspects of this work, especially with regard to the idea of positing, and Suzy Harris for helpful comments on the text as a whole. Notwithstanding my resistance to some of the suggestions that were made by reviewers (the reasons for which are, I hope, clear), I want to thank them for their strong endorsement of the line I have taken in the paper. The Editor is thanked for the suggestion that I place my response more explicitly in relation to the analytical/continental distinction - hence, the rather lengthy endnotes. 